\title{
Broken Promises: The Effect of Psychological Contract Violation on Student-Athlete Trust and Intentions to Leave Their Team
}

\author{
Christopher R. Barnhill \\ Georgia Southern University \\ Brian A. Turner \\ The Ohio State University
}

\begin{abstract}
The purpose of this study was to examine the impact that increased perceptions psychological contract breach between student-athletes and their coaches have on student-athletes' affective trust in their coaches, cognitive trust in their coaches, and intentions to leave their team. Based on a sample of 248 NCAA Division I and Division II student-athletes, the results reveal that increased perceptions of psychological contract breach significantly lower student-athletes' cognitive trust in their coaches and significantly increases their intentions to leave their team. Higher levels of psychological contract violation acted as a partial mediator on the relationship between psychological contract breach and cognitive trust. Psychological contract violation also acted as a partial mediator on the relationship between psychological breach and intentions to leave. Neither perceptions of psychological contract breach nor psychological contract violation were significantly related to affective trust.
\end{abstract}

Keywords: student-athletes, psychological contract, trust, intentions to leave, coaches

A substantial portion of the National Collegiate Athletic Association (NCAA) student-athlete population may not trust their coaches and or express disappointment in their school selection. These are two of the messages contained in the association's annual Growth, Opportunities, Aspirations, and Learning of Students in college (GOALS) report released at the 2011 NCAA Convention. The report highlighted the results of the 2010 GOALS study (Petr, Paskus, \& Miranda, 2011), which focused on the influence that coaches have over the student-athlete experience. At the Division I level, results ranged from only $56 \%$ of football players to $39 \%$ of

Barnhill is with the Dept. of Health and Kinesiology, Georgia Southern University, Statesboro, GA. Turner is with the Dept. of Sport Management, The Ohio State University, Columbus, OH. 
women's basketball players who agree that they can trust their coaches. The results were similar at the Division II and Division III levels.

Petr et al. (2011) found similar results when they asked student-athletes if they were happy with their school choice. At the Division I level results ranged from $70 \%$ to $48 \%$ of student-athletes who were glad they chose to attend their current school depending on sport. At the Division II level, results ranged from $63 \%$ to $49 \%$ of student-athletes who expressed similar contentment. Similar results were also reported at the Division III level. According to the NCAA ("Get the Facts," 2012), $6.4 \%$ of Division I student-athletes transferred to another four year institution during the 2010-11 academic year. Included in that figure were 200 baseball players, 445 men's basketball players, 364 women's basketball players, and 969 football players. The NCAA also states that, for a variety of reasons, approximately $40 \%$ of men's basketball student-athletes will not be competing at their original school by the end of their second year.

The trends highlighted in the GOALS report are disturbing. A substantial portion of student-athletes may not trust their coaches and are unhappy with their school selection. How can colleges and universities improve upon those numbers? Psychological contract theory may provide an answer. Psychological contract theory has gained wide acceptance as a framework to understand relations between employees and organizations (Taylor \& Tekleab, 2004). Researchers have found psychological contract theory to be a reliable predictor of important outcomes, such as trust (Deery, Iverson, \& Walsh, 2006; Robinson, 1996; Zhao, Wayne, Glibkowski, \& Bravo, 2007) and intentions to leave an organization (Bravo \& Won, 2009; Deery et al., 2006; Robinson, 1996; Zhao et al., 2007). In a recent study, Barnhill, Czekanski and Turner (2013) found that student-athletes do form psychological contracts with their coaches. The two main purposes of this study were to (a) determine the impact that increased perceptions of psychological contract breach and higher levels psychological contract violation have on student-athletes' trust in their coaches, and (b) examine the effects of psychological contract breach and psychological contract violation on student-athletes' intentions to leave their teams.

\section{Theoretical Framework}

\section{Psychological Contract Theory}

First used by Argyris (1960), psychological contract theory has been widely accepted by organizational behaviorists as a framework to understand relations between individuals and organizations (Taylor \& Tekleab, 2004; Zhao et al., 2007). Defined as, "individual beliefs, shaped by the organization, regarding the terms of an exchange agreement between individuals and their organization" (Rousseau, 1995, p. 9), psychological contracts serve as a framework for party members to understand complex and fluid relationships (1995).

Before a formal relationship, potential organizational members begin seeking information about their role with a future employer, club, team, or other type of organization (Rousseau 1990; 2001). Information, which can take be retrieved both explicitly (e.g., direct information from a manager or coach) and implicitly (e.g., second course data from websites), is often incomplete and misunderstood by the receiver (De Vos, Buyens, \& Schalk, 2003; Rousseau 2001). Depending on one's 
predispositions and career motives, individuals often interpret information differently than their peers (Bunderson, 2001; Rousseau, 2001). Once a formal relationship is established, new organizational members continue to seek information in an effort fill in the gaps and understand discrepancies that may exist between their interpretation and the organization's interpretation of the psychological contract (De Vos et al., 2003; De Vos, De Stobbeleir, \& Meganck, 2009; Rousseau, 2001). Often, organizational members interpret psychological contract terms favorably toward their own wishes over that of the organization (De Vos et al., 2009).

The ultimate goal of parties involved with a psychological contract is fulfillment. However, with few exceptions (Turnley, Bolino, Lester, \& Bloodgood, 2003), research indicates that complete contract fulfillment is rare due to the implicit, dynamic nature of many psychological contract terms (Robinson \& Rousseau, 1994; Rousseau, 1995). Psychological contract breach occurs when an individual perceives a discrepancy between what they believe they were promised and what they actually received from the organization (Morrison \& Robinson, 1997). Perceptions of psychological contract breach have been found to negatively affect the relationship between individuals and organizations. Lowered levels of job satisfaction (Bunderson, 2001; Cantisano, Dominguez Morales, \& Depolo, 2008; Robinson \& Rousseau, 1994), commitment to their organization (Bunderson, 2001; Cantisano et al., 2008; Coyle-Shapiro \& Kessler, 2000; McInnis, Meyer, \& Feldman, 2009), and trust in the organization (Cantisano et al., 2008; Deery et al., 2006; Pate, 2006; Robinson, 1996; Zhao et al., 2007), as well as increased organizational turnover intentions (Deery et al., 2006; Robinson, 1996; Robinson \& Rousseau, 1994), are common outcomes for individuals who perceive psychological contract breach.

Under certain circumstances, researchers have observed that psychological contract breach is associated with negative emotional reactions experienced by individuals (Morrison \& Robinson, 1997; Pate 2006; Rigiotti, 2009; Robinson \& Morrison, 2000). Morrison and Robinson (1997) termed the emotional reaction psychological contract violation. In differentiating between psychological contract breach and psychological contract violation, Morrison and Robinson stated, "We reserve the term violation for the emotional and affective state that may, under certain conditions, follow from the belief that one's organization has failed to adequately maintain the psychological contract" (p. 230).

Pate (2006) examined 50 cases of psychological contract breach and its outcomes. She found that in numerous cases, breaches resulted in little or no change to the relationship. However, in cases where the individual felt let down personally, they developed emotional feelings following the perceived breach. According to Pate's findings, relationships affected by a psychological contract violation are irreparable and result in significantly lower levels of organizational commitment, satisfaction, trust, organizational citizenship behaviors, and effort.

Pate (2006) is not alone in finding significant negative outcomes associated with high levels of psychological contract violation. High levels of psychological contract violation has been found to negatively impact trust in the organization (Kingshott \& Pecotich, 2007; Zhao et al., 2007), commitment (Suazo, Turnley, \& Mai-Dalton, 2005; Zhao, et al., 2007), satisfaction (Kickul, Lester, and Finkl, 2002; Zhao et al., 2007), organizational citizenship behavior (Suazo et al., 2005; Zhao et al., 2007), intentions to leave (Bravo \& Won, 2009; Suazo et al., 2005, Zhao et al., 2007), and performance (Suazo et al., 2005, Zhao et al., 2007). Suazo et al. 
(2005) found that psychological contract violation acted as a mediator between psychological contract breach and its affective outcomes. Zhao et al. (2007) had similar results.

\section{Trust}

It is clear that in corporate organizational settings, increased perceptions of psychological contract breach and higher levels of psychological contract violation are detrimental to trust (Cantisano et al., 2008; Deery et al., 2006; Pate, 2006; Robinson, 1996; Zhao et al., 2007). The relationship between psychological contracts and student-athletes' trust toward their coaches has received substantially less attention, and Barnhill et al.'s (2013) study represents the only work we identified to examine the relationship. They found that increased perceptions of psychological contract breach lowered student-athletes' trust in their coaches. Barnhill et al. did not examine psychological contract violation.

Despite the findings of Petr et al. (2011), the literature pertaining to trust between student-athletes and their coaches is also sparse. A study conducted by Judson, Aurand, and Karlovsky (2007) found that trust is built between studentathletes and coaches during recruitment. According to Judson et al.'s model, the relationship between student-athletes and coaches begins with little more than attraction to the university by the athlete. Over time, the relationship evolves and trust is developed. Judson et al. also found that most student-athletes did not fully develop trust until after they enrolled and began their first year at school. Tamminen and Holt (2012) examined adolescent athletes. They found that trust was built when athletes felt respected by their coaches. Jackson, Dimmock, Gucciardi, and Grove (2011) found that personality traits shared between coaches and athletes affect the growth of trust.

Athletes' trust in their coaches has positive benefits. Tamminen and Holt (2012) found that high levels of trust between athletes and coaches aides the teaching and learning process. A study of professional athletes in Spain by Mach, Dolan, and Tzafrir (2010) found that trust in coaches is a significant factor in team cohesion. They also found that team cohesion is a significant factor in team success. However, Judson et al. (2007) found that a loss of trust between student-athletes and their coaches can end the relationship.

Lewis and Weigart (1985) conceptualized trust as having two distinct components. Cognitive trust is a rational and calculative condition focusing on an individual's gains (Tyler \& Kramer, 1996). In terms of the relationship between student-athletes and their coaches, cognitive trust represents a rational calculation made by the student-athlete to partner with their coach for personal gain. Atkinson (2007) found that increased perceptions of psychological contract breach are negatively related to cognitive trust. As coaches and student-athletes communicate during the recruiting process, trust is built (Judson et al., 2007). If a student-athlete chose to partner with a coach based on perceived promises made during the recruiting process, it is reasonable to assume that she or he would be skeptical of partnering with the coach after perception of a broken promise. Therefore, we hypothesized:

Hypothesis 1: Increased perceptions of psychological contract breach will be negatively related to student-athletes' levels of cognitive trust in their coaches. 
We could not identify research focusing on psychological contract violation of student-athletes. However, numerous studies in other fields suggest psychological contract violation affects individuals' trust in their organizations (Kingshott \& Pecotich, 2007; Zhao et al., 2007). Suazo et al. (2005) found that psychological contract violation mediates the relationship between perceived psychological contract breach and dependent variables. A student-athlete who feels emotionally damaged because of a broken promise from their coaches may also experience strong negative reactions toward them, further lowering the cognitive trust. As such, we hypothesized:

Hypothesis 2: Psychological contract violation will partially mediate the relationship between perceived psychological contract breach and cognitive trust.

The second component of trust, as conceptualized by Lewis and Weigart (1985), is affective trust, or the relational bond between two parties affecting their respect and welfare concern they share for one another. Atkinson (2007) found a strong relationship between the psychological contract breach and affective trust. Several researchers have demonstrated the important role that relational bonds have in player/team development and success (Mach et al., 2010; Tamminen \& Holt, 2012). If a student-athlete has increased perceptions of psychological contract breach, it is reasonable to assume that affective trust between themselves and their coaches would be lowered. We would also expect a similar pattern for psychological contract violations. Therefore, we postulated:

Hypothesis 3: Increased perceptions of psychological contract breach will be negatively related to student-athletes' levels of affective trust in their coaches.

Hypothesis 4: Psychological contract violation will partially mediate the relationship between psychical contract breach and affective trust.

Judson et al. (2007) found that the relationship between student-athletes and coaches develops over time. In particular, they found that trust begins developing during early stages within the relationship but is not fully developed until the relationship matures. McAllister (1995) and Webber (2008) found that cognitive trust must develop before affective trust. Based on McAllister's (1995) and Webber's (2008) findings, we believe that student-athletes make a rational calculation to partner with their coaches before developing a relational bond to them. Thus, we predicted:

Hypothesis 5: Higher levels of cognitive trust will be positively related to student-athletes' affective trust in their coaches.

\section{Intentions to Leave}

Individuals who have increased perceptions of psychological contract breach or higher levels of psychological contract violation will seek to rebalance the relationship by lowering commitment, satisfaction, or performance (Rousseau, 1995). Under certain circumstances, the relationship is irreparably damaged and the individual's only recourse is to terminate the relationship (Pate, 2006; Robinson \& Rousseau, 1994). Student-athletes who wish to terminate their relationship with their team may find doing so difficult. NCAA regulations may force student-athletes to sit 
out a year of competition or allow current coaches to place restrictions on which institutions can offer grant in aid to a transfer. Student-athletes must also weigh the effect that transferring to another school will have on their academic outcomes. Zhao et al. (2007) define intention to leave as the affective feeling of wanting to terminate the relationship one's organization, and they suggest it represents a more appropriate measure than actual turnover because of the high external costs often associated with leaving an organization.

A number of scholars have found that increased perceptions of psychological contract breach impact intentions to leave of organizational members (Deery et al., 2006; Robinson, 1996; Robinson \& Rousseau, 1994). Barnhill et al. (2013) found that increased perceptions of psychological contract breach was positively related student-athletes' intentions to leave. Based on the available literature we assume that student-athletes who believe that their coaches broke a promise or promises to them will be more likely to want to leave their team. Therefore, we hypothesized:

Hypothesis 6: Increased perceptions of psychological contract breach will be positively related to student-athletes' intentions to leave.

While research examining these phenomena is lacking, a number of authors examining populations outside the team sports setting have found that psychological contract violation affects organizational members' desires to leave their organizations (Bravo \& Won, 2009; Deery et al., 2006; Robinson, 1996; Zhao et al., 2007). Suazo et al. (2005) found that psychological contract violation mediated the relationship between perceived psychological contract breach and intentions to leave. Based on the literature, it is reasonable to surmise that student-athletes will react similarly to other populations when experiencing higher levels of psychological contract violation. We posited:

Hypothesis 7: Psychological contract violation felt by student-athletes will partially mediate the relationship between psychological contract breach and intentions to leave.

\section{Factors Affecting Student-Athletes}

In addition to examining the aforementioned relationships, we were also interested in examining factors that might influence psychological contract breaches and violations. We identified three: coaching change, team tenure, and player gender.

Student-athletes often cite the importance of their relationships with their coaches and teammates on their experience (Klenosky, Templin, \& Troutman, 2001; Mathes \& Gurney, 1985; Rivera 2004). But, as Pate et al. (2011) point out, coaching changes can be a common occurrence for student-athletes to endure. Organizational transitions, such as a change in management, cause a reevaluation of the psychological contract by the individual (Chaudhry, Coyle-Shapiro, \& Wayne, 2011). Research suggests that individuals are more likely have increased perceptions of psychological breach during periods of change (Freese, Schalk, \& Croon, 2011; Robinson \& Morrison, 2000). Given these relationships, we hypothesized:

Hypothesis 8: Student-athletes who have experienced a change in head coach will have increased perceptions of psychological contract breach. 
Research suggests that individuals have higher psychological contract breach perception levels early in a relationship (De Vos et al., 2009). Over time, psychological contracts become more stable, but may become less so if organizational change occurs (2009). Unlike many relationships in other settings, the term of the student-athlete relationship with their team is preestablished. Student-athletes have five years to participate in four athletic seasons. Jubenville, Goss, and Phillips (2007) found that student-athletes' relationships with their coaches deteriorate over time. The results of Jubenville et al.'s study indicate that student-athletes may be more likely to experience increased perception of psychological contract breach later in their tenure with their team. Thus, we predicted:

Hypothesis 9: Student-athletes will experience increased perception of psychological contract breach in the later years of their tenure with their team.

Several recent studies have examined the impact of gender on psychological contract interpretation and outcomes. Blomme, van Rheede, and Tromp (2010) found that women and men react differently to breaches depending on the context of a perceived broken promise. Bellou (2009) found that women have higher expectations for their organization than do men. Women might also feel stronger about their own obligations to the organization (Tallman \& Bruning, 2008). However, Barnhill et al. (2013) found that male student-athletes were more likely to have increased perceptions of psychological contract breach than were females. Given these findings, we hypothesized:

Hypothesis 10: Male student-athletes will experience higher levels of perceived psychological contract breach than will female student-athletes.

\section{Method}

\section{Participants}

The participants in the survey were student-athletes enrolled at one of four universities located throughout the Midwestern and Southern United States. Three of the universities compete at the NCAA Division I level and account for 196 of the respondents $(79.0 \%)$. The fourth university competes at the NCAA Division II level and accounted for 52 of the respondents (21.0\%). In terms of demographics, 142 of the respondents $(57.3 \%)$ were female compared with 104 males $(41.9 \%)$. Two respondents did not give their gender. A majority of respondents were first year student-athletes $(n=87,35.1 \%)$, followed by second year student-athletes $(n=65$, $26.2 \%)$, third year student-athletes $(n=56,22.3 \%)$, and fourth year student-athletes $(n=30,12.1 \%)$. Five respondents identified themselves as fifth year student-athletes, and five other respondents did not provide their year in school. In addition, 47 (19.0\%) had experienced a change in head coaches while at the university.

\section{Measures}

Participants responded to a questionnaire in which they provided their demographic information and responded to items measuring psychological contract breach, psychological contract violation, cognitive trust, affective trust, and intentions to 
leave. Before we distributed the questionnaire, we asked a panel of five experts to review it for content validity evidence. Following the suggestions made by these individuals, appropriate changes to the instrument were made. For all multi-item scales, participants responded using a Likert scale ranging from 1 (strongly disagree) to 6 (strongly agree).

We measured psychological contract breach with four items adapted from Robinson and Morrison's (2000) global scale of psychological contract breach. To illustrate the nature of the adaptations, Robinson and Morrison's scale contains the item, "I have not received everything promised to me by my organization" To make the item relevant to the target population, it was adapted to, "I have not received everything promised to me by my coaches." The scale was reliable $(\alpha=.87)$.

Similarly, we measured psychological contract violation with four items adapted from Robinson and Morrison's (2000) emotional response to breach scale $(\alpha=.89)$. To demonstrate the changes made, Robinson and Morrison's scale contains the item, "I feel that my organization has violated the contract between us." We adapted the item to, "I feel that my coaches have violated the contract between us."

We adapted items from McAllister's (1995) affective trust and cognitive trust scales to measure those constructs. To exemplify the adaptions, McAllister's scale contains the affective trust item, "I can talk freely to this individual about difficulties I am having at work and know that (s)he will want to listen." We adapted the item to, "I can talk freely with my coaches about difficulties I am having and know that they will want to listen." Meanwhile, we adapted the McAllister's cognitive trust item, "This person approaches his/her job with professionalism and dedication," to "My coaches approach their job with professionalism." Both the cognitive trust $(\alpha=.90)$ and affective trust $(\alpha=.83)$ scales were reliable.

Intention to leave (intentions to leave) was measured using items inspired by Hackman and Oldham (1980). Their scale contained the single item, "I frequently think about leaving this organization." Hackman and Oldham's item was adapted to state, "I frequently think about leaving my team." Three additional items were added. An example included the item, "If all obstacles were removed, I would leave this team." The final scale demonstrated strong reliability $(\alpha=.83)$.

\section{Procedures}

We distributed questionnaires to student-athletes at three NCAA Division I universities located in the South and Midwest, and one Division II university in the Midwest. All of the Division I universities opted to distribute surveys through an athletic department representative. The athletic department representatives distributed the surveys at team meetings without the coaches in attendance. This was done to avoid potential biases caused by having coaches present during data collection. Each participant also received a stamped envelope allowing them to mail the questionnaire directly back to the researchers. This was done to protect the confidentiality of the participants. A total of 211 surveys were returned via mail, of which 196 were deemed usable. A rate of return could not be calculated, as we were unable to determine how many surveys were actually distributed by the athletic department representatives. The Division II university requested that the surveys be distributed online. The university supplied a list of 235 student-athlete emails and the surveys were distributed via Qualtrics.com. A total of 60 surveys were completed for a 
response rate of $25.5 \%$. Of the surveys completed via the Internet, 52 were deemed usable. Thus, we had a final sample of 248 student-athletes.

\section{Results}

We first calculated bivariate correlations, as seen in Table 1. The correlation matrix indicated a potential multicollinearity issue between several independent variables. Per Licht (1995), associations greater than .80 indicate highly correlated variables, and we observed this for the relationships between cognitive trust and both psychological contract violation $(r=-.84)$ and affective trust $(r=.83)$. To determine if multicollinearity posed a problem with the model, the variance inflation factor (VIF) for each of the independent variables was examined. VIF values of 10 or greater indicate redundancy among independent variables (Kline, 2011). The VIF values for the independent variables in the model were below 10, indicating that the independent variables were not redundant and that multicollinearity did not pose a threat to the model.

We examined the Hypotheses 1-7 via path analysis using Lisrel 8.8. Analysis of the path model revealed an acceptable fit. MacCallum, Browne, and Sugawara (1996) recommend a root mean squared error of approximation (RMSEA) of .08 or less. Our path model met their specifications (RMSEA = .08). Schumacker and Lomax (2004) recommend that a standardized root mean square residual (SRMR) of less than .05 indicates acceptable fit of the model. Our path model meets their recommendation $(S R M R=.01)$. Byrne $(1994)$ recommends that a goodness of fit index (GFI) of greater than .90 is demonstrates acceptable fit. Our model meets Byrne's recommendations $(\mathrm{GFI}=.99)$. The path model also had a comparative fit index $(\mathrm{CFI}=.99)$ that was greater than .95 as recommended by $\mathrm{Hu}$ and Bentler (1999). Chi square also indicated acceptable fit $\left(\chi^{2}=3.82, d f=2, p=.148\right)$. Because the path model had an acceptable fit, the relationships between the variables in the model were analyzed. The model explains approximately $58 \%$ of the variance in psychological contract violation, $68 \%$ of the variance in affective trust, $72 \%$ of the variance in cognitive trust, and $21 \%$ of the variance in intentions to leave. We present an illustrative summary of the findings in Figure 1.

Analysis of the path model revealed that most of the proposed hypotheses were accepted. With our first hypothesis, we predicted that increased perception of psychological contract breach would be negatively related to student-athletes' cognitive trust in their coaches. Results from the path analysis demonstrated

\section{Table 1 Inter-Item Correlation Matrix}

\begin{tabular}{lccccc}
\hline Item & $\mathbf{1}$ & $\mathbf{2}$ & $\mathbf{3}$ & $\mathbf{4}$ & $\mathbf{5}$ \\
\hline 1. Psychological contract breach & - & & & & \\
2. Psychological contract violation & $.76^{* *}$ & - & & & \\
3. Affective trust & $-.63^{* *}$ & $-.72^{* *}$ & - & & \\
4. Cognitive trust & $-.74^{* *}$ & $-.84^{* *}$ & $.83^{* *}$ & - & \\
5. Intentions to leave & $.46^{* *}$ & $.49^{* *}$ & $-.41^{* *}$ & $-.41^{* *}$ & - \\
\hline
\end{tabular}

** Significant at the .01 level. 


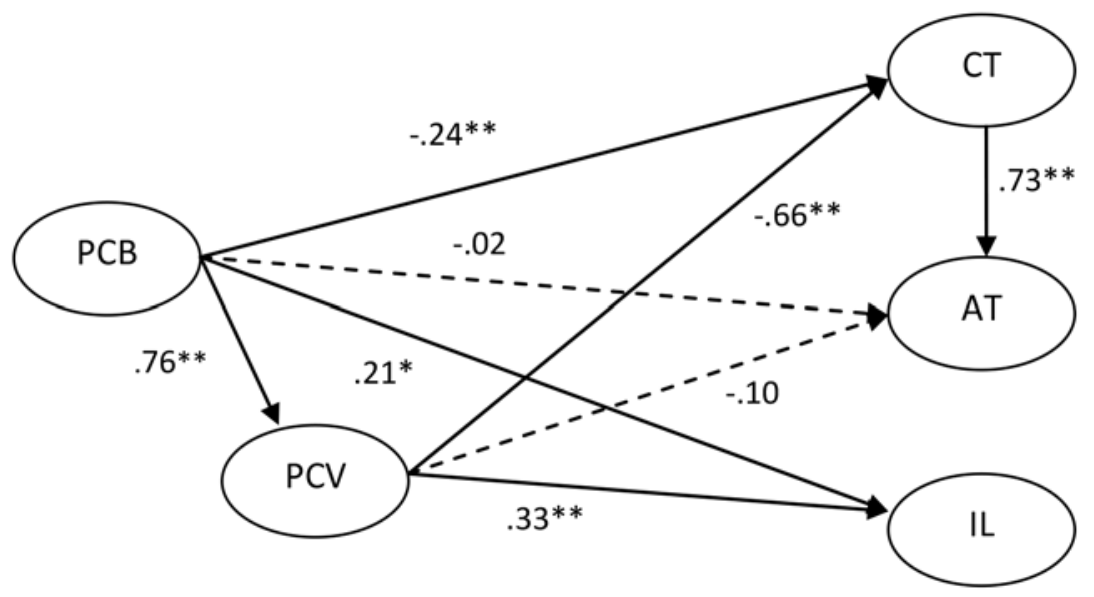

Figure 1 - Illustrative summary of the effects of psychological breaches and violations. Notes. $\mathrm{PCB}=$ psychological contract breach. $\mathrm{PCV}=$ Psychological contract violation. $\mathrm{CT}$ $=$ Cognitive trust. $\mathrm{AT}=$ Affective trust. $\mathrm{IL}=$ Intentions to leave. $* * p<.01 .{ }^{*} p<.05$.

support for this hypothesis $(\beta=-.24, p<.01)$. Likewise, with Hypothesis 2 , we predicted that psychological contract violation would partially mediate the relationship between psychological contract breach and cognitive trust. Path analysis revealed that psychological contract breach has a significant positive relationship with psychological contract violation $(\beta=.76, p<.01)$, and psychological contract violation also has a significant negative relationship with cognitive trust $(\beta=-.66$, $p<.01)$. Thus, student-athletes' levels of psychological contract violation partially mediated the relationship between psychological contract breach and cognitive trust, supporting Hypothesis 2.

Hypotheses 3 and 4 were related to the relationships among psychological contract breach, psychological contract violation, and affective trust. Hypothesis 3 was rejected, as the relationship between psychological contract breach and affective trust was not statistically significant $(\beta=-.02$, n.s. $)$. We also predicted that psychological contract violation would partially mediate the relationship between psychological contract breach and affective trust (Hypothesis 4). This hypothesis was rejected because psychological contract breach was not significantly related to affective trust.

Hypothesis 5 held that cognitive trust would be positively related to affective trust, and this was accepted $(\beta=.73, p<.01)$.

Hypotheses 6 and 7 examined the relationships between psychological contract breach, psychological contract violation, and student-athletes' intentions to leave their team. Hypothesis 6 was accepted, as there was a significant positive relationship between psychological contract breach and intentions to leave $(\beta=$ $.21, p<.05)$. Hypothesis 7 predicted that level of psychological contract violation would partially mediate the relationship between psychological contract breach and intentions to leave. As noted above, psychological contract breach was significantly, 
positively related to psychological contract violation. Model testing revealed that psychological contract violation has a significant positive relationship with intentions to leave $(\beta=.33, p=01)$. Thus, hypothesis 7 was accepted.

Hypothesis 8 stated that student-athletes who have experienced a coaching change would be more likely to have increased perceptions psychological contract breach. The mean response from student-athletes who had experienced a head coach change on items pertaining to psychological contract breach was $2.96(S D=$ 1.13). Student-athletes who had not experienced turnover of their head coach had a mean response of $2.46(S D=1.24)$. The difference between the two groups was significant, $t(244)=2.50, p=.013$, thereby supporting Hypothesis 8 .

We expected student-athletes would be more likely to have increased perceptions psychological contract breach in their later years on the team than they would in their earlier years (Hypothesis 9). To determine if year in school impacted the likelihood that a student-athlete would perceive psychological contract breach, we conducted a one-way analysis of variance (ANOVA). The ANOVA revealed that there was a significant difference, $F(4,238)=3.29, p=.01$, between student-athletes perceptions of psychological contracts breach based on year in school. A Dunnett T3 post hoc test of the ANOVA revealed that student-athletes in their fourth year in school $(M=3.18)$ are significantly more likely to perceive psychological contract breach than those in their first year $(M=2.28$, Mean Difference $=.90, p=.017)$. Thus, the hypothesis was supported.

Our final hypothesis (H10) stated that male student-athletes would be more likely to have higher perception levels for psychological contract breach than would female student-athletes. An independent samples $t$-test was conducted to determine whether gender impacted the likelihood that a student-athlete would perceive psychological contract breach. The mean scores for psychological contract breach among women $(M=2.49, S D=1.23)$ and men $(M=2.66, S D=1.24)$ did not vary from one another, $t(244)=-1.05, p=.297$; thus, Hypothesis 10 was rejected.

\section{Discussion}

The two main purposes of this study were to (a) determine the impact that increased perception of psychological contract breach and higher levels of psychological contract violation have on student-athletes' trust in their coaches, and (b) examine the role of psychological contract breaches and psychological contract violations have on student-athletes' intentions to leave their teams. Collectively, our findings suggest that when student-athletes believe that their coaches have failed to fulfill obligations or perceived promises, their relationships with their coaches and team are altered. Cognitive trust in their coaches will be lowered, meaning student-athletes will become more skeptical of their coaches and feel less confident in their chances that a partnership will result in personal gain. Student-athletes also become more likely to feel a negative emotional reaction, called psychological contract violation. Higher levels of psychological contract violation will lower cognitive trust. Student-athletes who perceive increased levels of psychological contract breach are also likely to contemplate feelings about leaving their team. If psychological contract violation feelings are high, intentions to leave are likely to be stronger. The result is a student-athlete who desires to terminate the relationship. However, obstacles in place may prevent the student-athlete from actually terminating the 
relationship, creating a scenario where a student-athlete is forced to continue a relationship essentially against their own desires.

In addition to testing our path model, we examined three factors that might affect student-athletes' perceptions or reactions to the psychological contract they have with their coaches. Our finding that gender was not a significant factor in determining whether a student-athlete would perceive psychological contract breach was surprising because it was contradictory to the findings of Barnhill et al. (2013). Recently, several studies have found that women and men perceive psychological contracts differently (Bellou, 2009; Blomm, van Rheede, \& Tromp, 2010; Tallman $\&$ Bruning, 2008). More research needs to be done in this area.

Our finding that student-athletes in their fourth year on their team were significantly more likely to have increased perceptions psychological contract breach than student-athletes in their first year was not surprising (see also Jubenville et al., 2007). It is possible that student-athletes in their fourth year on their team have developed increasing complicated psychological contracts with their coaches. As a contract becomes more complex and includes more terms, there is a greater chance that an obligation could be broken (Rousseau, 1995). A second possible reason that student-athletes in their fourth year are more likely to perceive a breach may lie in the fixed nature of the contract. Student-athletes in their fourth year are nearing the end of their possible tenure on their team. They may be realizing that their time with team will soon be ending and prior promises may go unfulfilled. Further research in this area is warranted.

Perhaps the least surprising outcome of the study was that student-athletes who have experienced a coaching change are more likely to experience higher perceptions of psychological contract breach. Major organizational changes have been found to increase perceptions of psychological contract breach (Chaudhry et al., 2011; Freese et al., 2011). In terms of an intercollegiate sports team, turnover at head coach can be considered a monumental change for student-athletes to endure. The goals and culture of the team may be altered, the role of student-athletes may be altered, and the new coach may have little or no knowledge of promises made by individuals who are no longer part of the team or staff.

\section{Implications}

The results of this study provide a number of implications for coaches and intercollegiate athletics administrators. First and foremost, it should be noted that this study further validated the notion of the existence of psychological contracts between student-athletes and their coaches. It also illustrated the destructive power that emotional feelings, known as psychological contract violation can have on trust and student-athletes' intentions to leave their team.

Knowing that student-athletes do indeed form psychological contracts based off the perceived obligations they have of their coaches suggests the need for clear and open communication channels between coaches and athletes, especially during the recruiting phase of the relationship. It is during recruiting that the psychological contract is formed (DeVos et al., 2003; DeVos et al., 2009; Rousseau 1990; 2001). At the same time, organizational representatives are often unaware or misinformed about the individual's perception of the contract (Morrison \& Robinson, 1997). Setting clear standards and defined roles from the inception of a relationship is a key to 
avoiding breaches of the psychological contract (Rousseau, 1995). Open communication regarding mutual obligations will allow for the formation of a better alignment between student-athletes' perceptions of coaches obligations and actual intentions.

The results of this study also provide possible answers for the disturbing trends found by Petr et al. (2011) regarding student-athletes' trust in their coaches and satisfaction with their school selection. The development of trust between studentathletes and coaches begins during recruitment (Judson et al., 2007). Prerelationship assumptions of obligations are a critical factor in student-athletes' assessments of the psychological contract. It is during recruitment that coaches must wear many hats. They must build a relationship with the student-athlete while also acting as a salesperson. It is possible that student-athletes may be misreading the sales pitches of the coaches as promises of obligations to guide a future relationship. Studentathletes with increased perceptions of psychological contract breach were more likely to lower their level of cognitive trust in their coaches and entertain thoughts of leaving their teams. Feelings of violation magnified the affect. Rousseau (1995) suggested that breaches can be avoided, or their impact can be mitigated, through explicit communication lines between organizational members and continuous vigilance of party obligations. If a breach is detected, coaches should act quickly to relay their reasons for the breach.

This study underscores the importance of clear, explicit communication throughout the duration of the relationship. Athletic departments can help their coaches through a number of methods. Training regarding what the psychological contract is and how it affects their relationships with the student-athletes is important. Communication channels between coaches, student-athletes, and administrators could be developed as well. Providing procedures that allow the psychological contract parties to express their concerns and discuss expectations, especially following a breach, may negate or limit potential damages (Rousseau, 1995). Schools may also conduct surveys following recruitment and at the conclusion of each season to determine how well the coach is performing in communicating and fulfilling obligations.

\section{Limitations}

There are several limitations to the current study that must be acknowledged. First, we used a convenience sample, thus limiting its generalizability to the overall population of student-athletes. A second major limitation was our inability to control for scholarship level. A scholarship is an implicit promise and an integral part of a psychological contract between student-athletes and their coaches. However, several of the participating schools asked us to remove items pertaining to scholarship levels as they felt it may harm anonymity of the participants. It is possible that scholarship level may impact student-athletes' perceptions of the psychological contract. Along those same lines, several schools asked us not to gather information regarding which sport the participants played. It is possible that student-athletes from different sports may perceive psychological contracts differently. Future studies must control for scholarship and sport. Finally, we found that several factors (i.e., year in school and changes in coach) impacted the likelihood that a student-athlete would perceive a psychological contract breach. It is possible that these factors may have altered the model. Ideally, the sample should have been split into groups based on these factors and path analysis should have been conducted to see if the path model is 
altered. Our sample size was not large enough to split the model and therefore we cannot say whether the entire model would be altered for student-athletes who have experienced a coaching change or year in school.

\section{Recommendations for Future Studies}

This study added to the small but growing body of literature regarding psychological contracts and relationships between intercollegiate student-athletes and their coaches. Studies such as this one, as well as those by Antunes de Campos (1994) and Barnhill et al. (2013), suggest that psychological contracts between coaches and student-athletes function much like those in other organizational settings. Psychological contract breach and psychological contract violation do predict negative outcomes for the team and individual. That said, the finding that increased perception of psychological contract breach and higher levels of psychological contract violation only had a direct impact on cognitive trust was surprising. Robinson (1996) argued that the relationship between trust and the psychological contract has not received enough attention. Pate (2006) noted that many relationships continue after a perceived breach even though levels of trust are altered. Only one prior study (Atkinson, 2007) has examined the relationship using Lewis and Weigart's (1985) conceptualization. Further research examining the relationship between affective trust, cognitive trust, and psychological contracts is needed to advance the understanding of this important but misunderstood relationship.

As noted in the limitations, we were unable to control for scholarship level or sport in this study. A scholarship would represent an explicit term in the psychological contract between coaches and student-athletes. Future studies should control for scholarship levels to determine if athletes on full scholarship are more or less likely to perceive a breach than those who are on partial or no scholarship. Controlling for sport will allow researchers to determine whether student-athletes who participate in revenue producing sports perceive the psychological contract differently than those in Olympic sports.

Finally, while this and several other studies (Antunes de Campos, 1994; Barnhill et al. 2013) have indicated the importance of understanding psychological contracts between coaches and athletes, we have little cognition of their content. An understanding of the content of the psychological contract between coaches and studentathletes is critical. The use of content specific measures allows the researchers to identify inducements that are more or less likely to result in perceived breaches or violations of the psychological contract. Rousseau and Tijoriwala (1998) referring to content specific measures state, "This approach promises more stable, generalizable measures of discrete contract terms across populations, an advantage for those researchers interested in specific obligations such as pay or promotion" (p. 688). Psychological contract research will become infinitely more useful for athletics directors and coaches if researchers can determine what obligations student-athletes believe are part of the contract. In addition, which obligations, when broken, are apt to lead to feelings of psychological contract violation. Robinson and Morrison (2000), De Vos et al. (2003), and De Vos et al. (2009) each used scales that identified specific psychological contract content relative to their sample populations. Future research should focus on creating a content specific scale for the relationship between coaches and student-athletes as well. 


\section{References}

Antunes de Campos, P. (1994). The relationship between coaches and athletes: The strength of the psychological contract in sports (Unpublished doctoral dissertation). Alliant International University, San Diego, CA.

Argyris, C. (1960). Understanding organizational behavior. Homewood, intentions to leave: Dorsey Press, Inc.

Atkinson, C. (2007). Trust and the psychological contract. Employee Relations, 29, 227-246. doi:10.1108/01425450710741720

Barnhill, C.R., Czekanski, W.A., \& Turner, B.A. (2013). Psychological contracts and studentathlete retention. Journal for the Study of Sports \& Athletes in Education, 7(1). doi:1 0.1179/1935739713Z.0000000002

Bellou, V. (2009). Profiling the desirable psychological contract for different groups of employees: evidence from Greece. International Journal of Human Resource Management, 20, 810-830. doi:10.1080/09585190902770711

Blomme, R.J., van Rheede, A., \& Tromp, D.M. (2010). The use of the psychological contract to explain turnover intentions in the hospitality industry: a research study on the impact of gender on the turnover intentions of highly educated employees. International Journal of Human Resource Management, 21, 144-162. doi:10.1080/09585190903466954

Bravo, G., \& Won, D. (2009, May). Giving and receiving: An examination of the psychological contract in NCAA coaches. Paper presented at the meeting of the North American Society for Sport Management, Columbia, SC.

Bunderson, J.S. (2001). How work ideologies shape the psychological contracts of professional employees: Doctors' responses to perceived breach. Journal of Organizational Behavior, 22, 717-741. doi:10.1002/job.112

Byrne, B.M. (1994). Structural equation modeling with EQS and EQS/Windows. Thousand Oaks, CA: Sage Publications.

Cantisano, G.T., Morales Dominguez, J.F., \& Depolo, M. (2008). Psychological contract breach and outcomes: Combining meta-analysis and structural equation models. Psicothema, 20, 487-496. PubMed

Chaudhry, A., Coyle-Shapiro, J.A.M., \& Wayne, S.J. (2011). A longitudinal study of the impact or organizational change on transactional, relational, and balanced psychological contracts. Journal of Leadership \& Organizational Studies, 18, 247-259. doi:10.1177/1548051810385942

Coyle-Shapiro, J., \& Kessler, I. (2000). Consequences of the psychological contract for the employment relationship: A large scale survey. Journal of Management Studies, 37, 903-930. doi:10.1111/1467-6486.00210

De Vos, A., Buyens, D., \& Schalk, R. (2003). Psychological contract development during organizational socialization: Adaptation to reality and the role of reciprocity. Journal of Organizational Behavior, 24, 537-559. doi:10.1002/job.205

De Vos, A., De Stobbeleir, K., \& Meganck, A. (2009). The relationship between career-related antecedents and graduates' anticipatory psychological contracts. Journal of Business and Psychology, 24, 289-298. doi:10.1007/s10869-009-9107-3

Deery, S.J., Iverson, R.D., \& Walsh, J.T. (2006). Toward a better understanding of psychological contract breach: A study of customer service employees. The Journal of Applied Psychology, 91, 166-175. PubMed doi:10.1037/0021-9010.91.1.166

Freese, C., Schalk, R., \& Croon, M. (2011). The impact of organizational changes on psychological contracts: A longitudinal study. Personnel Review, 40, 404-422. doi: $10.1108 / 00483481111133318$

Get the facts about transfers. (2012, May). Latest News. Retrieved from http://www. ncaa.org/wps/wcm/connect/public/NCAA/Resources/Latest+News/2012/May/ Get+the+facts+about+transfers 
Hackman, J.R., \& Oldham, G.R. (1980). Work redesign. Reading, MA: Addison-Wesley.

$\mathrm{Hu}$, L.T., \& Bentler, P.M. (1999). Cutoff criteria for fit indexes in covariance structure analysis: conventional criteria versus new alternatives. Structural Equation Modeling, 6, 1-55. doi:10.1080/10705519909540118

Jackson, B., Dimmock, J.A., Gucciardi, D.F., \& Grove, J.R. (2011). Personality traits and relational perceptions in coach-athlete dyads: Do opposites really attract? Psychology of Sport and Exercise, 12, 222-230. doi:10.1016/j.psychsport.2010.11.005

Klenosky, D.B., Templin, T.J., \& Troutman, J.A. (2001). Recruiting student-athletes: A means-end investigation of school-choice decision making. Journal of Sport Management, 15, 95-106.

Jubenville, C.B., Goss, B.D., \& Phillips, D.R. (2007). Student-athlete perceptions of the coach/athlete relationship and their impact on intercollegiate sports programs: An interpretive case study of small-college head football coaches. International Journal of Sport Management, 8, 147-169.

Judson, K.M., Aurand, T.W., \& Karlovsky, R.W. (2007). Applying relationship marketing principals in the university setting: An adaptation of the exchange relationship typology. The Marketing Management Journal, 17, 184-197.

Kickul, J., Lester, S.W., \& Finkl, J. (2002). Promise breaking during radical organizational change: Do justice interventions make a difference? Journal of Organizational Behavior, 23, 469-488. doi:10.1002/job.151

Kingshott, R.P.J., \& Pecotich, A. (2007). The impact of psychological contracts on trust and commitment in supplier-distributor relationships. European Journal of Marketing, 41, 1053-1072. doi:10.1108/03090560710773345

Kline, R.B. (2011). Principles and practice of structural equation modeling (3rd ed.). New York, NY: Guilford Press.

Lewis, J.D., \& Weigart, A. (1985). Trust as a social reality. Social Forces, 63, 967-985.

Licht, M.H. (1995). Multiple regression and correlation. In L.G. Grimm \& P.R. Yarnold (Eds.), Reading and understanding multivariate statistics (pp. 19-64). Washington, DC: American Psychological Association.

Mach, M., Dolan, S., \& Tzafrir, S. (2010). The differential effect of team members' trust on team performance: The mediation role of team cohesion. Journal of Occupational and Organizational Psychology, 83, 771-794. doi:10.1348/096317909X473903

MacCallum, R.C., Browne, M.W., \& Sugawara, H.M. (1996). Power analysis and determination of sample size for covariance structure modeling. Psychological Methods, 1 , 130-149. doi:10.1037/1082-989X.1.2.130

Mathes, S., \& Gurney, G. (1985). Factors in student-athletes' choice of colleges. Journal of College Student Personnel, 26, 327-333.

McAllister, D.J. (1995). Affect- and cognition based trust as foundations for interpersonal cooperation in organizations. Academy of Management Journal, 38, 24-59. doi: $10.2307 / 256727$

McInnis, K.J., Meyer, J.P., \& Feldman, S. (2009). Psychological contracts and their implications for commitment: A feature-based approach. Journal of Vocational Behavior, 74, 165-180. doi:10.1016/j.jvb.2008.12.007

Morrison, E.W., \& Robinson, S.L. (1997). When employees feel betrayed: A model of how psychological contract violation develops. Academy of Management Review, 22, 226-256.

Pate, J. (2006). The changing contours of the psychological contract: Unpacking context and circumstances of breach. Journal of European Industrial Training, 30(1), 32-47. doi:10.1108/03090590610643860

Pate, J.R., Stokowski, S.E., \& Hardin, R. (2011). Third time's a charm: The case of Tennessee's four junior football players who endured three different head coaches in three seasons. Journal of Issues in Intercollegiate Athletics, 4, 354-369. 
Petr, T., Paskus, T., \& Miranda, M. (2011, January). Examining the student-athlete experience through the NCAA GOALS and SCORE studies. Paper presented at the 2011 NCAA Convention, San Antonio, TX.

Rigiotti, T. (2009). Enough is enough? Threshold models for the relationship between psychological contract breach and job related attitudes. European Journal of Work and Organizational Psychology, 18, 442-463. doi:10.1080/13594320802402039

Rivera, C.A. (2004). The Identification of Key Factors Student-Athletes Perceived to be important to the College Student-Athlete Retention Process. Unpublished doctoral dissertation, The Ohio State University.

Robinson, S.L. (1996). Trust and breach of the psychological contract. Administrative Science Quarterly, 41, 574-599. doi:10.2307/2393868

Robinson, S.L., \& Morrison, E.W. (2000). The development of psychological contract breach and violation: A longitudinal study. Journal of Organizational Behavior, 21, 525-546. doi:10.1002/1099-1379(200008)21:5<525::AID-JOB40>3.0.CO;2-T

Robinson, S.L., \& Rousseau, D.M. (1994). Violating the psychological contract: Not the exception but the norm. Journal of Organizational Behavior, 15, 245-259. doi:10.1002/ job.4030150306

Rousseau, D.M. (1990). New hire perceptions of their own and their employer's obligations: A study of psychological contracts. Journal of Organizational Behavior, 11, 389-400. doi:10.1002/job.4030110506

Rousseau, D.M. (1995). Psychological contracts in organizations: Understanding written and unwritten agreements. Thousand Oaks, CA: Sage Publications.

Rousseau, D.M. (2001). Schema, promise and mutuality: The building blocks of the psychological contract. Journal of Occupational and Organizational Psychology, 74, 511-541. doi:10.1348/096317901167505

Rousseau, D.M., \& Tijoriwala, S.A. (1998). Assessing psychological contracts: Issues, alternatives and measures. Journal of Organizational Behavior, 19, 679-695. doi:10.1002/ (SICI)1099-1379(1998)19:1+<679::AID-JOB971>3.0.CO;2-N

Schumacker, R.E., \& Lomax, R.G. (2004). A beginner's guide to structural equation modelin (2nd ed.). Mahwah, N.J: Lawrence Erlbaum.

Suazo, M.M., Turnley, W.H., \& Mai-Dalton, R.R. (2005). The role of perceived violation in determining employees' reactions to psychological contract breach. Journal of Leadership \& Organizational Studies, 12, 24-36. doi:10.1177/107179190501200104

Tallman, R.R.J., \& Bruning, N.S. (2008). Relating employees' psychological contracts to their personality. Journal of Managerial Psychology, 23, 688-712. doi:10.1108/02683940810894756

Tamminen, K.A., \& Holt, N.L. (2012). Adolescent athletes' learning about coping and the roles of parents and coaches. Psychology of Sport and Exercise, 13, 69-79. doi:10.1016/j.psychsport.2011.07.006

Taylor, M.S., \& Tekleab, A.G. (2004). Taking stock of psychological contract research: Assessing progress, addressing troublesome issues, and setting research priorities. In J. A. CoyleShapiro, L. M. Shore, M. S. Taylor, \& L. E. Tetrick (Eds.), The employment relationship: Examining psychological and contextual perspectives (pp. 253-283). New York: Oxford.

Turnley, W.H., Bolino, M.C., Lester, S.W., \& Bloodgood, J.M. (2003). The impact of psychological contract fulfillment on the performance of in-role and organizational citizenship behaviors. Journal of Management, 29, 187-206. doi:10.1177/014920630302900204

Tyler, T.R., \& Kramer, R.M. (1996). Whither trust? London: Sage Publications.

Webber, S.S. (2008). Development of cognitive and affective trust in teams: A longitudinal study. Small Group Research, 39, 746-769. doi:10.1177/1046496408323569

Zhao, H., Wayne, S.J., Glibkowski, B.C., \& Bravo, J. (2007). The impact of psychological contract breach on work-related outcomes: A meta-analysis. Personnel Psychology, 60, 647-668. doi:10.1111/j.1744-6570.2007.00087.x 